\title{
Prone position reduces lung stress and strain in severe acute respiratory distress
} syndrome

\author{
S.D. Mentzelopoulos*, C. Roussos" ${ }^{\#}$ and S.G. Zakynthinos $\#$
}

ABSTRACT: The present authors hypothesised that in severe acute respiratory distress syndrome (ARDS), pronation may reduce ventilator-induced overall stress (i.e. transpulmonary

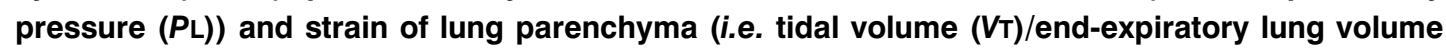
(EELV) ratio), which constitute major ventilator-induced lung injury determinants. The authors sought to determine whether potential pronation benefits are maintained in post-prone semirecumbent (SRPP) posture under pressure-volume curve-dependent optimisation of positive end-expiratory pressure (PEEP).

A total of 10 anesthetised/paralysed, mechanically ventilated $\left(V T=9.0 \pm 0.9 \mathrm{~mL} \cdot \mathrm{kg}^{-1}\right.$ predicted body weight; flow $=0.91 \pm 0.04 \mathrm{~L} \cdot \mathrm{s}^{-1}$; PEEP $=9.4 \pm 1.3 \mathrm{cmH}_{2} \mathrm{O}$ ) patients with early/severe ARDS were studied in pre-prone semirecumbent (SRBAS), prone, and SRPP positions. Partitioned respiratory mechanics were determined during iso-flow $\left(0.91 \mathrm{~L} \cdot \mathrm{s}^{-1}\right)$ experiments (VT varied within 0.2-1.0 L), along with haemodynamics, gas exchange, and EELV.

Compared with SRBAS, pronation/SRPP resulted in reduced peak/plateau $P$ L at $V$ TS $\geqslant 0.6$ L; static lung elastance and additional lung resistance decreased and chest wall elastance (in prone position) increased; EELV increased (23-33\%); VT/EELV decreased (27-33\%); arterial oxygen tension/inspiratory oxygen fraction and arterial carbon dioxide tension improved (21-43/10$14 \%$, respectively), and shunt fraction/physiological dead space decreased (21-50/20-47\%, respectively).

In early/severe acute respiratory distress syndrome, pronation under positive end-expiratory pressure optimisation may reduce ventilator-induced lung injury risk. Pronation benefits may be maintained in post-prone semirecumbent position.

KEYWORDS: Acute respiratory distress syndrome, gas exchange, lung recruitment, mechanical ventilation, mechanics of the respiratory system, prone position

I n mechanically ventilated patients, lung stress and strain are major determinants of ventilator-induced lung injury (VILI) [1-5]. Alveolar stress (i.e. transmural pressure) is the ratio of alveolar wall tension to thickness. Thus, plateau/peak transpulmonary pressure $(P \mathrm{~L})$ reflects overall lung parenchymal stress [2, 3]. Strain is distending force-induced lung parenchyma deformation, and corresponds to the tidal volume $(V \mathrm{~T})$ /end-expiratory lung volume (EELV) ratio [3].

Acute respiratory distress syndrome (ARDS) patients are VILI susceptible, due to disorderinduced lung regional collapse/consolidation, which severely constrains normally aerated lung parenchyma [6-8]. VILI prevention comprises low $V \mathrm{~T}$ use, positive end-expiratory pressure
(PEEP), and prone positioning [3]. Low $V \mathrm{~T}$ ventilation $\left(6 \mathrm{~mL} \cdot \mathrm{kg}^{-1}\right)$ may not be advantageous relative to "standard" $V \mathrm{~T}$ ventilation (8$9 \mathrm{~mL} \cdot \mathrm{kg}^{-1}$ ) [9]. PEEP may cause circulatory depression [10], increase pulmonary oedema $[11,12]$, and contribute to VILI by inducing lung regional overdistension $[12,13]$. In severe ARDS with diffuse and bilateral aeration loss [8, 13, 14], PEEP-induced overinflation risk is reduced, even at high PEEP $\left(17 \mathrm{cmH}_{2} \mathrm{O}\right)$ [15]. However, lung overdistension (excessive pressure applied to acutely-injured parenchyma) can occur without concomitant overinflation [14]; consequently, the rationale for optimal PEEP level selection (PEEP optimising arterial oxygenation and minimising oxygen toxicity/VILI risks) still holds. Prone positioning may attenuate VILI [15-17]. Prone position causes more homogenous lung inflation

\section{AFFILIATIONS}

*University of Athens Medical School, Dept of Intensive Care Medicine, Attikon University Hospital, and

\#University of Athens Medical School, Dept of Intensive Care Medicine, Evaggelismos General Hospital, Athens, Greece.

\section{CORRESPONDENCE}

S.D. Mentzelopoulos 12 Ioustinianou Street GR-11473

Athens

Greece

Fax: 302103218493

E-mail: sdm@hol.gr

Received:

September 092004

Accepted after revision:

November 192004

SUPPORT STATEMENT

The present work was funded solely by the Dept of Intensive Care Medicine, University of Athens Medical School, Evaggelismos General Hospital, Athens, Greece.

European Respiratory Journal Print ISSN 0903-1936 Online ISSN 1399-3003 
and eliminates lung compression by the heart and abdominal contents, thus limiting atelectasis [14, 18, 19]. Semirecumbent positioning may also attenuate cardiac/abdominal lung compression relative to a supine position [14]. Consequently, in severe ARDS, the elucidation of the effects of PEEP/body positioning optimisation [14] with respect to major VILI determinants might be of considerable clinical importance.

The present authors tested the hypothesis that following PEEP optimisation, prone positioning may reduce $P \mathrm{~L}$ and $V \mathrm{~T} / \mathrm{EELV}$ relative to pre-prone semirecumbent (SRBAS) in patients with early/severe ARDS. The current authors also sought to determine whether the potential pronation benefits are maintained in the post-prone semirecumbent (SRPP) posture. Total respiratory system (RS), chest wall and lung mechanics, and haemodynamics/gas exchange were also determined and compared among the aforementioned body postures.

\section{MATERIAL AND METHODS \\ Patients}

Institutional Review Board (Evaggelismos General Hospital, Scientific Committee, Athens, Greece) approval and informed/ written next-of-kin consent were obtained. A total of 10 consecutive patients with early (disorder diagnosis established within the preceding $72 \mathrm{~h}$ ) and severe ARDS (table 1) [20] were enrolled between July 14, 2003 and July 12, 2004. ARDS was defined as acute onset, arterial oxygen tension $\left(\mathrm{Pa}_{\mathrm{O}} \mathrm{O}_{2}\right) /$ inspiratory oxygen fraction $\left(\mathrm{F} \mathrm{I}_{\mathrm{O}}\right)<200 \mathrm{mmHg}$ (regardless of PEEP level), bilateral infiltrates on frontal chest radiograph, and wedge pressure $<18 \mathrm{mmHg}$ [21]. Inclusion criteria with respect to ARDS severity were $\mathrm{Pa}_{\mathrm{a}} \mathrm{O}_{2} / \mathrm{Fi}_{\mathrm{i}} \mathrm{O}_{2} \leqslant 100 \mathrm{mmHg}$, and a "white lungs" feature (hyperattenuation areas equally disseminated within upper and lower lung lobes) [20] on frontal chest radiograph. Radiographs were independently evaluated by two independent radiologists. Exclusion criteria included age $<18$ yrs, pregnancy, intracranial hypertension, burns $>30 \%$ of body surface area, spine fractures, smoking and/or chronic respiratory disease, chronic liver disease (Child-Pugh class C) [22], neuromuscular disease impairing spontaneous breathing, sickle cell disease, and body mass index $>27.5 \mathrm{~kg} \cdot \mathrm{m}^{-2}$.

During the 6-h duration study-period, patient care was provided by an independent physician. New/additional administration of i.v. fluid boluses, inotropes, antipyretics, antiarrhythmic treatment, or diuretics led to patient exclusion

TABLE 1 Patient characteristics prior to inclusion to the study

\begin{tabular}{|c|c|c|c|c|c|c|c|c|c|c|c|c|}
\hline $\begin{array}{l}\text { Patient } \\
\text { No. }\end{array}$ & $\begin{array}{l}\text { Age } \\
\text { yrs }\end{array}$ & Sex & $\begin{array}{c}\text { BMI } \\
\mathrm{kg} \cdot \mathrm{m}^{-2}\end{array}$ & $\begin{array}{l}\text { SAPS II } \\
\text { score }^{\#}\end{array}$ & $\begin{array}{l}\text { Murray } \\
\text { Score }\end{array}$ & 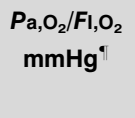 & $\begin{array}{c}{\mathrm{Pa}, \mathrm{CO}_{2}} \\
\mathrm{mmHg}^{\circ}\end{array}$ & $\mathrm{FI}_{1, \mathrm{O}_{2}}{ }^{\circ}$ & $\begin{array}{l}\text { PEEPe } \\
\mathrm{cmH}_{2} \mathrm{O}^{-}\end{array}$ & $\begin{array}{c}V_{T} \mathrm{~L} / \mathrm{V} T \\
\mathrm{~mL} \cdot \mathrm{kg}^{-1} \\
\mathrm{PBW}^{\bullet}\end{array}$ & $\begin{array}{c}\mathrm{P}_{2, \text { aw }} \\
\mathrm{cmH}_{2} \mathrm{O}^{\text {厂 }}\end{array}$ & $\begin{array}{c}\text { Respiratory } \\
\text { disease }\end{array}$ \\
\hline
\end{tabular}

\begin{tabular}{|c|c|c|c|c|c|c|c|c|c|c|c|c|c|}
\hline 1 & 50 & $M$ & 22.4 & 51 & 3.25 & 96.3 & 48.2 & 0.7 & 11 & $0.49 / 6.9$ & 25.3 & $\begin{array}{c}\text { Staphylococcus } \\
\text { Pneumonia }^{+}\end{array}$ & S \\
\hline 2 & 40 & $M$ & 21.7 & 52 & 3.50 & 94.4 & 49.2 & 0.7 & 12 & $0.48 / 7.1$ & 26.6 & $\begin{array}{c}\text { Legionella } \\
\text { Pneumonia }\end{array}$ & S \\
\hline 3 & 43 & $\mathrm{~F}$ & 21.3 & 59 & 3.75 & 91.1 & 51.1 & 0.8 & 13 & $0.51 / 9.1$ & 35.0 & $\begin{array}{l}\text { Streptococcus } \\
\text { Pneumonia }^{+}\end{array}$ & D \\
\hline 4 & 33 & M & 22.2 & 53 & 3.50 & 88.9 & 52.3 & 0.8 & 13 & $0.49 / 7.1$ & 29.3 & $\begin{array}{c}\text { Legionella } \\
\text { Pneumonia }\end{array}$ & S \\
\hline 5 & 26 & $M$ & 23.1 & 54 & 4.00 & 79.0 & 52.5 & 0.8 & 14 & $0.5 / 7.0$ & 33.2 & $\begin{array}{c}\text { Staphylococcus } \\
\text { Pneumonia }^{+}\end{array}$ & D \\
\hline 6 & 52 & $\mathrm{~F}$ & 20.7 & 61 & 3.75 & 83.3 & 48.8 & 0.8 & 14 & $0.5 / 8.5$ & 32.9 & $\begin{array}{c}\text { Klebsiella } \\
\text { Pneumonia }^{+}\end{array}$ & S \\
\hline 7 & 47 & $M$ & 23.5 & 50 & 3.25 & 93.8 & 52.4 & 0.7 & 11 & $0.5 / 7.1$ & 27.7 & $\begin{array}{l}\text { Streptococcus } \\
\text { Pneumonia }^{+}\end{array}$ & S \\
\hline 8 & 37 & M & 21.7 & 82 & 4.00 & 76.0 & 50.9 & 0.9 & 16 & $0.45 / 6.2$ & 39.5 & $\begin{array}{c}\text { Staphylococcus } \\
\text { Pneumonia }^{+}\end{array}$ & $D$ \\
\hline 9 & 44 & $M$ & 21.4 & 79 & 4.00 & 79.1 & 50.3 & 0.9 & 16 & $0.46 / 6.3$ & 39.8 & $\begin{array}{c}\text { Staphylococcus } \\
\text { Pneumonia }^{+}\end{array}$ & D \\
\hline 10 & 34 & $\mathrm{~F}$ & 22.6 & 62 & 3.25 & 93.3 & 49.3 & 0.8 & 14 & $0.49 / 8.4$ & 29.1 & $\begin{array}{l}\text { Streptococcus } \\
\text { Pneumonia }^{+}\end{array}$ & $S$ \\
\hline
\end{tabular}

Patient No. refers to the order of enrolment to the study. Patients were mechanically ventilated at volume assist-control mode; inspiratory flow ranged within $0.6-0.9 \mathrm{~L} \cdot \mathrm{S}^{-1}$; respiratory rate (range $19-28 \cdot \mathrm{min}^{-1}$ ) was adjusted to maintain an arterial $\mathrm{pH}$ of $\geqslant 7.30$. For males, predicted body weight was calculated as $=50+($ Height $(\mathrm{cm})-$ $152.4) \times 0.91$; for females, 50 was replaced by 45.5 . Patients weaned from mechanical ventilation and discharged from the intensive care unit (ICU) were considered as survivors. BMI: body mass index; SAPS II: simplified acute physiology score II; $\mathrm{Pa}_{1} \mathrm{O}_{2}$ : arterial oxygen tension; $\mathrm{FI}_{1} \mathrm{O}_{2}$ : inspiratory oxygen fraction; $\mathrm{Pa}, \mathrm{CO}_{2}$ : carbon dioxide arterial tension; PEEPe: externally applied positive end-expiratory pressure; $V T$ : tidal volume; PBW: predicted body weight; $P 2$,aw: plateau tracheal pressure; M: male; $\mathrm{S}$ survival; F: female; D: death (in the ICU). \#: on ICU admission; ${ }^{*}$ : variables recorded just prior to study enrolment, whilst there was no patient-ventilator asynchrony in any case; ${ }^{+}$: microorganism isolated in tracheobronchial aspirates (positive cut-off value $=10^{5}$ colony forming units $\cdot \mathrm{mL}^{-1}$ ); ${ }^{\S}$ : diagnosis established by PCR for Legionella and detection of Legionella antigen in urine. 
[23]. Electrocardiographic lead II, peripheral intra-arterial and pulmonary artery (continuous cardiac output $/ \mathrm{S}_{\mathrm{v}}, \mathrm{O}_{2}$ catheter; Baxter, Deerfield, IL, USA) pressures, urinary bladder temperature, and peripheral oxygen saturation $\left(\mathrm{Sa}_{\mathrm{a}} \mathrm{O}_{2}\right)$ were monitored continuously [23].

\section{Mechanical ventilation}

Prior to study enrolment, patients were sedated (propofol/ fentanyl infused at $3.5-4.0 \mathrm{mg} \cdot \mathrm{kg}^{-1} \cdot \mathrm{h}^{-1} / 1.5-2.0 \mu \mathrm{g} \cdot \mathrm{kg}^{-1} \cdot \mathrm{h}^{-1}$, respectively), orotracheally intubated and mechanically ventilated (Siemens 300C ventilator; Siemens AG, Berlin, Germany) in a "near-supine" position $\left(20-30^{\circ}\right.$ inclination relative to horizontal). Intermittent neuromusculuar blockade was employed according to recent recommendations [24]. PEEP $\left(13.4 \pm 1.8 \mathrm{~cm} \mathrm{H}_{2} \mathrm{O}\right), \mathrm{FI}_{1} \mathrm{O}_{2}(0.79 \pm 0.07)$, and breathing rate $\cdot \mathrm{min}^{-1}$ (range 19-28) were set according to the ARDS Network protocol [25] (table 1). $V \mathrm{~T} \quad\left(0.49 \pm 0.02 \mathrm{~L}=7.4 \pm 0.9 \mathrm{~mL} \cdot \mathrm{kg}^{-1}\right.$ predicted body weight (PBW)) was adjusted so that plateau tracheal pressure $\left(P_{2}\right.$,aw $)$ was $<35 \mathrm{cmH}_{2} \mathrm{O}$, or kept within 6.0 $6.5 \mathrm{~mL} \cdot \mathrm{kg}^{-1} \mathrm{PBW}$ if $\mathrm{P}$,aw exceeded $35 \mathrm{cmH}_{2} \mathrm{O}$ (table 1 ). $\mathrm{Sa}_{1} \mathrm{O}_{2}$ achieved was $93.4 \pm 1.1 \%$. Following study enrolment, anaesthesia and neuromuscular blockade were induced/ maintained with additional propofol/fentanyl (induction bolus $=0.5 \mathrm{mg} \cdot \mathrm{kg}^{-1} / 50 \mu \mathrm{g}$ and maintenance infusion $=3.5-$ $4.0 \mathrm{mg} \cdot \mathrm{kg}^{-1} \cdot \mathrm{h}^{-1} / 1.5-2.0 \mu \mathrm{g} \cdot \mathrm{kg}^{-1} \cdot \mathrm{h}^{-1}$, respectively) and cisatracurium (intermittent administration targeted to full train-of-four inhibition throughout the study-period [23]), respectively, and body posture was changed to "steep" semirecumbent $\left(60^{\circ}\right.$ inclination, SRBAS). Prior to cisatracurium administration, oesophageal and gastric balloons were inserted and their correct placement was verified as previously described [2628]. Study-period baseline ventilator settings (volume-controlled mode) were: $F \mathrm{I}_{1} \mathrm{O}_{2}=0.79 \pm 0.07$ (as above); $V \mathrm{~T}=0.6 \pm 0.03 \mathrm{~L}$ $\left(9.0 \pm 0.9 \mathrm{~mL} \cdot \mathrm{kg}^{-1} \mathrm{PBW}\right)$; inspiratory flow $\left(V^{\prime}\right)=0.91 \pm 0.04 \mathrm{~L} \cdot \mathrm{s}^{-1}$; breathing rate $\cdot \mathrm{min}^{-1}=16-25$ (adjusted to maintain an arterial $\mathrm{pH}>7.30$ ) [24]; plateau pressure time $=0 \mathrm{~s}$; and $\mathrm{PEEP}=$ $9.4 \pm 1.3 \mathrm{~cm} \mathrm{H}_{2} \mathrm{O}$. PEEP was set at $2.0 \mathrm{cmH}_{2} \mathrm{O}$ above the lower inflection points of the pressure-volume curves, which were constructed as previously reported [20]. PEEP adjustment should not cause a $\mathrm{Pa}, \mathrm{O}_{2} / \mathrm{FI}_{1} \mathrm{O}_{2}$ decrease of $>5 \mathrm{mmHg}$. Employed PEEP/VT should not result in a plateau $P_{\mathrm{L}}\left(P_{2, \mathrm{~L}}\right)$ $>30 \mathrm{cmH}_{2} \mathrm{O}$. SRPPSa, $\mathrm{O}_{2}$ was $92.0 \pm 1.0 \%$.

\section{Protocol and measurements}

Investigational interventions were separated by $15 \mathrm{~min}$ of baseline ventilation for the re-establishment of baseline conditions [29]. Patients were sequentially studied in the SRBAS, prone $\left(0^{\circ}\right.$ inclination $)$, and SRPP $\left(60^{\circ}\right.$ inclination $)$ postures (2-h study duration for each posture). Patient turning was performed as previously described [23]. Following pronation, abdominal movement restriction was minimised as in previous studies [23, 30]. Any pronation-induced hypoxaemia $\left(\mathrm{Sa}_{1} \mathrm{O}_{2} \leqslant 90 \%\right)$ would result in protocol termination, and body posture change with ventilatory parameter adjustment as necessary. The reliability of oesophageal pressure (Poes) measurements was tested as before (fig. 1) [23].

The Poes tracing in figure $1 \mathrm{~d}$ is the average of the tracings of the four sigh test breaths administered to the patient; all other tracings originate from the first of the four test sighs. On
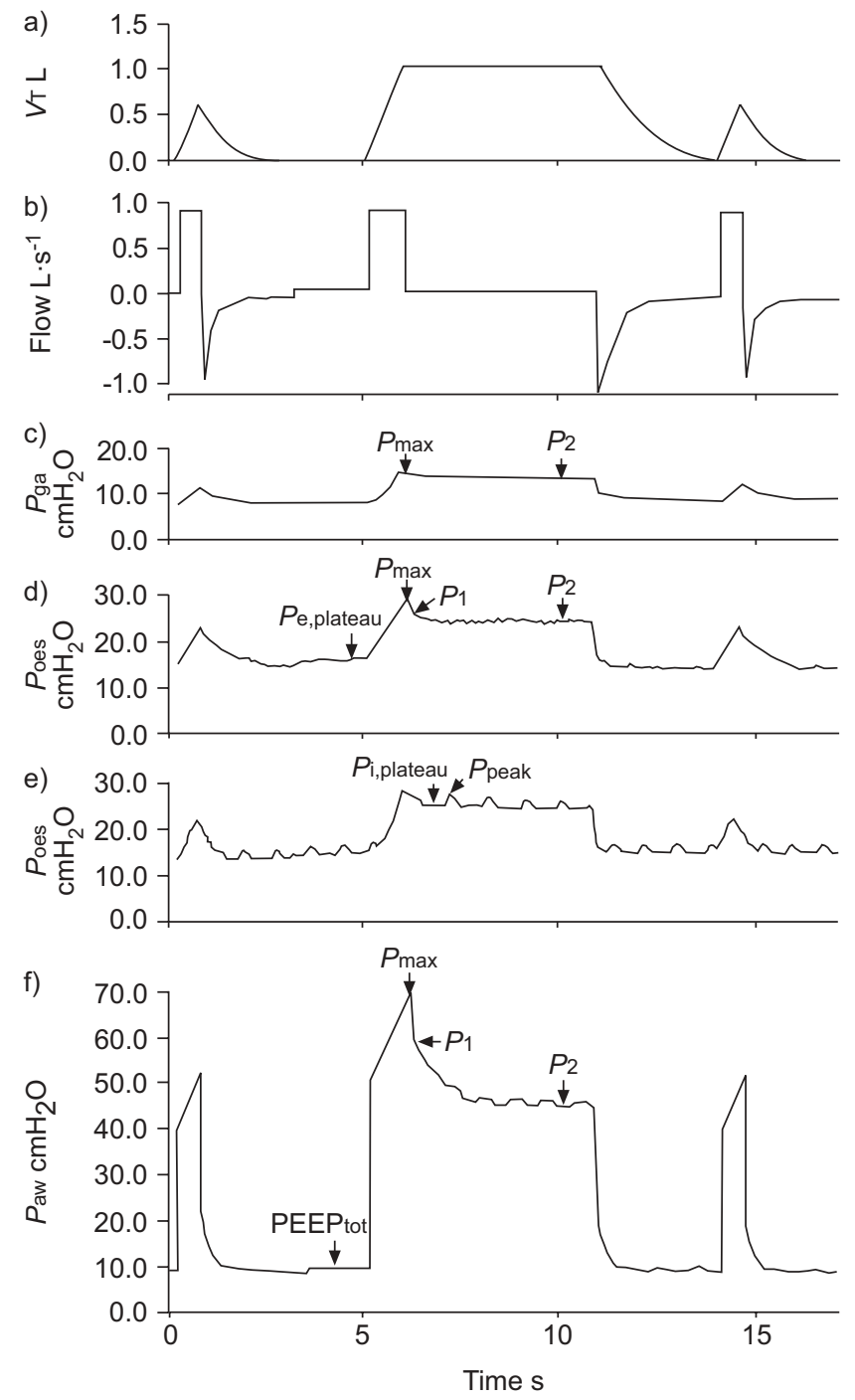

FIGURE 1. Assessment of respiratory mechanics. Presented variable data originate from a representative study participant. a) Tidal volume $(\mathrm{V} T), \mathrm{b})$ flow, and c) gastric $\left(P_{\text {ga }}\right)$, d and e) oesophageal $\left(P_{\text {oes }}\right)$ and f) tracheal pressure ( $P$ aw $)$ data printout, showing two baseline ventilation mechanical breaths $\left(V_{T}=0.6 \mathrm{~L}\right.$; inspiratory flow $\left.=0.91 \mathrm{~L} \cdot \mathrm{s}^{-1}\right)$ separated by a "sigh" test breath $\left(V_{T}=1.0 \mathrm{~L}\right.$; inspiratory flow $\left.=0.91 \mathrm{~L} \cdot \mathrm{S}^{-1}\right)$. Pmax: peak inspiratory pressure; $P_{2}$ : plateau inspiratory pressure; $P$ e,plateau: end-expiratory occlusion plateau pressure of $P_{o e s ;} P_{1}$ : pressure immediately after end-inspiratory airway occlusion; $P$ i,plateau: inspiratory plateau pressure; Ppeak: oscillation peak pressure; PEEPtot: total positive end-expiratory pressure. $P$ aw values were referred to atmospheric pressure. $P$ ga and averaged $P$ oes values were referred to respective values at respiratory system relaxation volume. $P$ e,plateau was used for determination of PEEPtot of the chest wall.

individual test breath Poes tracings (figure 1e), the maximal amplitude of each cardiac oscillation was measured as the difference between oscillation peak pressure (Ppeak) and the immediately preceding inspiratory plateau pressure $\left(P_{i}\right.$,plateau). For each cardiac oscillation, Poes rise rate was determined as the time needed for $P$ oes to rise from $P$ i,plateau to $P$ peak during that particular oscillation. For each Poes tracing, the mean maximal amplitudes of all cardiac oscillations, and mean $P$ oes rise rates during these oscillations were analysed; for each set 
of test breaths, the aforementioned variables were averaged and compared among study postures.

\section{Respiratory mechanics}

Inspiratory flow $\left(V^{\prime}\right), V \mathrm{~T}$, and tracheal $(P a w), P$ oes, and gastric $(P$ ga $)$ pressures were measured with a Hans-Rudolph pneumotachograph (pneumotachometer; Hans Rudolph Inc. Kansas City, MT, USA) and Validyne pressure-transducers (Validyne, Nortridge, CA, USA) [23]. Following analogue-todigital conversion, variable data were stored on an IBM-type computer for later analysis with Anadat software (RHTInfoData, Montreal, QC, Canada) [23]. During data sampling, variable tracings were displayed on a dedicated monitor and recorded (Gould ES 1000 electrostatic recorder; Gould Electronics Inc., Eastlake, OH, USA). Breathing circuit modifications included humidifier-removal and low compliance tubing [23]. Care was taken to avoid gas leaks. Equipment dead space (endotracheal tube (ETT) not included) was $90 \mathrm{~mL}$.

Respiratory mechanics were assessed with constant $V^{\prime}$ rapid airway occlusion. Within 30-60 min after study-posture assumption, sets of four test breaths were administered with a constant, square-wave $V^{\prime}\left(0.91 \mathrm{~L} \cdot \mathrm{s}^{-1}\right) . V \mathrm{~T}$ was sequentially varied from 0.6 (baseline) to $0.2,0.4,0.6,0.8$, and 1.0 (“sigh") L. During sighs, the maximum allowable $P 2, \mathrm{~L}$ was $45 \mathrm{~cm} \mathrm{H}_{2} \mathrm{O}$. Test breaths were separated by 1-min baseline ventilation periods (fig. 1).

Test breaths were preceded by 2-s duration end-expiratory occlusions, enabling determination of RS, chest wall, and abdominal chest wall-component total PEEP (PEEPtot) (fig. 1); the latter was always $\sim 0$. For Poes, end-expiratory occlusionplateaus were obtained by ensemble averaging [31] of Poes tracings of each test breath-set (fig. 1). Expiratory occlusions were followed by 4-6-s duration end-inspiratory occlusions, enabling determination of maximal pressure $(P \max )$, and pressure immediately after initiation of end-inspiratory occlusion $(P 1)$, and plateau pressure $\left(P_{2}\right)$ on computer-stored $P$ aw tracings, and of $P \max$ and $P_{2}$ on computer-stored $P$ ga tracings (fig. 1). For $P_{\text {oes, }} P_{\max } / P_{1}$ and $P 2$, values were determined after ensemble tracing-averaging of each set of test breaths [31] (fig. 1). Paw values were referred to atmospheric pressure, and $P$ oes $/ P$ ga values were referred to their values at respiratory system relaxation volume $(V \mathrm{r})$; the latter values were determined during the below-described measurements of the change $(\Delta)$ in functional residual capacity (FRC). For each set of test breaths, $P_{\mathrm{L}}$ was determined as the difference between the average $P$ aw value and the averaged $P$ oes. Total RS, chest wall, and lung inspiratory mechanical properties were computed by standard formulas (see Appendix 1).

\section{Haemodynamics and gas exchange}

In each posture, intravascular pressure transducers (Abbott, Sligo, Ireland) were set to zero at right-atrial level. Within 75$90 \mathrm{~min}$ after posture assumption, end-expiratory central venous and pulmonary artery wedge pressures were determined consecutively three times during respective 10-s duration ETT disconnections from the breathing circuit. ETT disconnections were separated by two 6-min duration baseline-ventilation intervals, over which heart rate, mean arterial/pulmonary artery pressure, cardiac output, and mixed-venous oxygen saturation values were recorded and averaged. Just prior to each ETT disconnection, mixed-venous and arterial blood gas samples were taken and analysed immediately (ABL System 625 blood-gas analyser model; Radiometer, Copenhagen, Denmark). After collecting the gases expired within $2 \mathrm{~min}$ prior to the second and third ETT disconnection, physiological dead space was determined as previously described [30]. Formula-derived variables included cardiac, systemic and pulmonary vascular resistance index, oxygen consumption/delivery, oxygen extraction ratio $\left(\mathrm{O}_{2} \mathrm{ER}\right)$, right/left ventricular stroke work index (SWI), respiratory quotient, alveolar oxygen partial pressure $\left(\mathrm{PO}_{2}\right)$, and shunt fraction (see Appendix 2).

\section{$\triangle \mathrm{FRC}$ and end-expiratory lung volume}

Within 105-120 min after study-posture assumption, baselineventilation $\triangle F R C$ was determined twice as previously reported [32], by allowing exhalation to $V$ r. Expiratory $V^{\prime}$ always reached $0 \mathrm{~L} \cdot \mathrm{s}^{-1}$ within $<10 \mathrm{~s}$. The two $\triangle$ FRC measurements were separated by $17 \mathrm{~min}$ of baseline ventilation. Immediately after each $\triangle F R C$ measurement, FRC was determined with the closed-circuit helium dilution technique as previously explained [30, 33-35]. Helium concentration was measured with a helium-analyser (PK Morgan Ltd, Kent, UK). Heliumdilution technique limitations have been previously analysed [36]. Baseline ventilation EELV was computed as the sum of measured FRC and $\triangle F R C$.

\section{Statistical analysis}

For each posture, only the means of obtained sets of measurements were analysed. Variable comparisons were conducted with two-factor univariate ANOVA for repeated measures, followed by the Scheffé test as appropriate. Significance was accepted at $\mathrm{p}<0.05$. Values are presented as mean $\pm \mathrm{SD}$.

\section{RESULTS}

Full data were obtained from all study participants and no protocol-related complications occurred [37]. Of the 10 patients, six were weaned from mechanical ventilation $15.2 \pm 3.1$ days after its institution and discharged from the intensive care unit (ICU) after another 2-3 days and four patients died of multiple system organ failure (table 1).

$\triangle F R C$, PEEPtot of the RS and chest wall, and Pga were unaffected by body posture (table 2). Poes at $V$ r did not differ significantly among study postures (table 2). The mean maximal amplitude and mean rise rate of Poes-cardiac oscillations (fig. 1), were similar (table 2). Consequently, the initial, correct oesophageal balloon positioning relative to the heart was maintained throughout the study period, and Poes measurements were as accurate as possible in all study postures [23]. The oesophageal balloon technique has been adopted in previous studies and is considered adequate in the prone position [30, 33, 35, 38].

\section{Tracheal pressure, oesophageal pressure and transpulmonary pressure}

$P$ aw was unaffected by body posture (fig. 2a). $P_{1} / P_{2}$ of averaged Poes tracings were higher in prone versus SRBAS/ SRPP at $V$ Ts $\geqslant 0.6 \mathrm{~L}(\mathrm{p}<0.05-0.01$; fig. $2 \mathrm{~b})$. Maximal $P_{\mathrm{L}}\left(P_{\max , \mathrm{L}}\right)$ was lower in prone/SRPP versus SRBAS at $V$ Ts $\geqslant 0.6-0.8 \mathrm{~L}$ $(\mathrm{p}<0.05-0.01)$. The $P_{1}$ value of $P_{\mathrm{L}}(P 1, \mathrm{~L})$ was lower in prone/SRPP versus SRBAS at VTs $\geqslant 0.4-0.6 \mathrm{~L} \quad(\mathrm{p}<0.05-0.01)$. 


\begin{tabular}{|c|c|c|c|}
\hline & Pre-prone semirecumbent & Prone & Post-prone semirecumbent \\
\hline PEEPtot, $\mathrm{RS} \mathrm{cmH}_{2} \mathrm{O}^{\#}$ & $11.3 \pm 1.5$ & $10.4 \pm 1.7$ & $10.1 \pm 1.5$ \\
\hline PEEPtot,cw $\mathbf{c m H}_{2} \mathrm{O}^{\#}$ & $2.8 \pm 0.4$ & $3.3 \pm 0.7$ & $2.6 \pm 0.4$ \\
\hline Poes at $\mathrm{Vr} \mathrm{cmH}_{2} \mathrm{O}$ & $12.6 \pm 3.1$ & $8.6 \pm 3.6$ & $12.4 \pm 3.0$ \\
\hline$\Delta P_{\text {max }}$,ga at $0.6 \mathrm{LVT} \mathrm{cmH}_{2} \mathrm{O}^{\#}$ & $3.7 \pm 1.1$ & $4.2 \pm 1.3$ & $3.9 \pm 1.1$ \\
\hline$\Delta P_{\max , g a}$ at $1.0 \mathrm{LVT} \mathrm{cmH}_{2} \mathrm{O}$ & $5.6 \pm 1.9$ & $6.0 \pm 2.4$ & $5.9 \pm 2.0$ \\
\hline$\Delta P_{2}, \mathrm{ga}$ at $0.6 \mathrm{LVT} \mathrm{cmH}_{2} \mathrm{O}^{\#}$ & $3.3 \pm 0.9$ & $3.9 \pm 1.1$ & $3.6 \pm 1.0$ \\
\hline$\Delta P_{2}$, ga at $1.0 \mathrm{~L} \mathrm{VT} \mathrm{cmH}_{2} \mathrm{O}$ & $5.3 \pm 1.5$ & $5.7 \pm 1.9$ & $5.5 \pm 1.6$ \\
\hline Mean maximal amplitude in Poes $\mathrm{cmH}_{2} \mathrm{O}^{\circ}$ & $2.0 \pm 1.2$ & $1.7 \pm 1.0$ & $2.1 \pm 1.3$ \\
\hline Mean rise rate in Poes $\mathrm{cmH}_{2} \mathrm{O} \cdot \mathrm{s}^{-19}$ & $12.5 \pm 5.2$ & $11.4 \pm 4.7$ & $12.8 \pm 5.3$ \\
\hline
\end{tabular}

Data are presented as mean \pm SD. $\triangle F R C$ : change in functional residual capacity; PEEPtot: total positive end-expiratory pressure; RS: respiratory system; $\mathrm{CW}$ : chest wall; $P$ oes: oesophageal pressure; $V_{r}$ : respiratory system relaxation volume; $P$ ga: gastric pressure; $\Delta P$ max,ga: difference between maximal $P$ ga and $P$ ga at $V_{r}$; $V T$ : tidal volume; $\Delta P_{2}$,ga: difference between plateau $P$ ga and $P$ ga at $V_{r}$. ${ }^{*}$ : values correspond to baseline ventilation conditions; ${ }^{\prime}$ : for each study posture, reported values are mean $\pm S D$ of determined values during all sets of test breaths (see also fig. 1).

$P 2, \mathrm{~L}$ was lower in prone/SRPP versus SRBAS at $V \mathrm{Ts} \geqslant 0.6 \mathrm{~L}$

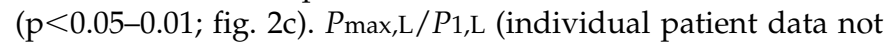
shown), and $P 2, \mathrm{~L}$ exhibited similar response patterns to posture change in all patients. Figure 3 displays individual $P_{2, L} V \mathrm{~T}$ relationships.

\section{EELV and $\mathrm{V} T / E E L V$}

In prone and SRPP, baseline-ventilation EELV was significantly higher versus SRBAS (by $30.3 \pm 1.6 \%$ and $23.9 \pm 1.0 \%$, respectively, $\mathrm{p}<0.01$; table 3 ). Accordingly, the baseline-ventilation $V \mathrm{~T}(0.6 \mathrm{~L}) / \mathrm{EELV}$ ratio, was lower in prone and SRPP versus SRBAS $\quad(0.41 \pm 0.04$ and $0.42 \pm 0.04$, respectively, versus $0.58 \pm 0.05, \mathrm{p}<0.01)$. The sigh $(1.0 \mathrm{~L}) V \mathrm{~T} / \mathrm{EELV}$ ratio was also lower in prone and SRPP versus SRBAS $(0.68 \pm 0.06$ and $0.71 \pm$ 0.06 , respectively, versus $0.97 \pm 0.09, \mathrm{p}<0.01)$. VT $/$ EELV exhibited similar response patterns to body posture in all patients.

\section{Respiratory mechanics}

Figure 4 displays the main results for the respiratory mechanics. Static chest wall elastance was higher in prone versus SRBAS/SRPP at VTs $\geqslant 0.6 \mathrm{~L}(\mathrm{p}<0.05-0.01)$. Additional lung resistance was lower in prone/SRPP versus SRBAS at all employed $V$ Ts $(\mathrm{p}<0.01)$. Static lung elastance $\left(E_{\text {stat }, \mathrm{L})}\right)$ was lower in prone/SRPP versus SRBAS at VTs $\geqslant 0.6 \mathrm{~L}(\mathrm{p}<0.05-0.01)$.

\section{Haemodynamics and gas exchange}

Table 4 displays the main results. Directly determined haemodynamic variables were not significantly affected by posture change. The $\mathrm{O}_{2} \mathrm{ER}$ exhibited sequential significant decreases from SRBAS to SRPP. Left vetricular SWI became higher in SRPP versus SRBAS. All gas exchange variables (including $\mathrm{Pa}_{1} \mathrm{O}_{2} / \mathrm{FI}_{1} \mathrm{O}_{2}$, carbon dioxide arterial tension, shunt fraction, and physiological dead space) were significantly improved in prone/SRPP versus SRBAS.

\section{DISCUSSION}

The present study has shown that in severe ARDS [8, 13, 14, 20], prone positioning under PEEP optimisation reduces ventilation-induced stress (reflected by $P_{\mathrm{L}}$ ) and strain (reflected by $V \mathrm{~T} / \mathrm{EELV}$ ) relative to $60^{\circ} \mathrm{SRBAS}$; these effects are maintained within $2 \mathrm{~h}$ following return to $60^{\circ} \mathrm{SRPP}$. Although only 10 patients were studied, individual response patterns of $P \mathrm{~L}$ and $V \mathrm{~T} / \mathrm{EELV}$ to posture change were similar. Favourable results occur with a baseline $(0.6 \mathrm{~L})$ to $1.0 \mathrm{~L} \mathrm{VTs}$ (range $8.2-17.6 \mathrm{~mL} \cdot \mathrm{kg}^{-1} \mathrm{PBW}$ for participants in the present study). The lowest of the aforementioned $V$ Ts are similar to the $8-9 \mathrm{~mL} \cdot \mathrm{kg}^{-1} V$ Ts routinely used by physicians studying/ treating patients with acute lung injury/ARDS [9, 39-42]. Other pronation benefits, also maintained in SRPP, included decreased Estat,L and additional lung resistance, improved arterial oxygenation, and reduced shunt fraction and $\mathrm{Pa}, \mathrm{CO}_{2}$ and physiological dead space; these findings are consistent with previously published results [30, 37, 43-45].

In the present study, PEEP was optimised to $4.0 \pm 0.9 \mathrm{cmH}_{2} \mathrm{O}$ lower values relative to the pre-study PEEP. PEEP optimisation was aimed at: 1) maintaining pre-study arterial oxygenation in SRBAS; and 2) allowing for a $V \mathrm{~T}$ increase of $1.7 \pm 0.2 \mathrm{~mL} \cdot \mathrm{kg}^{-1}$ PBW during the study period, without concomitant end-inspiratory stress increase to potentially injurious levels exceeding $30 \mathrm{cmH}_{2} \mathrm{O}(P 2, \mathrm{~L}$ in fig. 2c) [5, 46]. Posture change from near-supine to steep SRBAS may have facilitated the achievement of the aforementioned ventilation goals by partially relieving abdominal/cardiac compression of dependent/caudal lung regions [14].

Substantial lung mechanics/gas exchange benefits were obtained only after the pronation manoeuvre. The selection of the $0.6 \mathrm{~L}$ baseline $V \mathrm{~T}$ probably facilitated the intratidal alveolar recruitment [30, 47]; the optimised PEEP probably facilitated the maintenance of such recruitment [47]. Also, the employed $1.0 \mathrm{~L}$ sighs were probably more effective in the prone position [48]. The combined EELV and $\mathrm{Pa}_{1} \mathrm{O}_{2} / \mathrm{FI}_{1} \mathrm{O}_{2}$ increases and the shunt fraction decrease indicate effective re-aeration of well perfused, but previously collapsed lung units $[18,23,30,49]$. The $P 2, \mathrm{~L}$ and Estat,L reductions indicate pronation-induced reversal of regional atelectasis [23, 30]. 

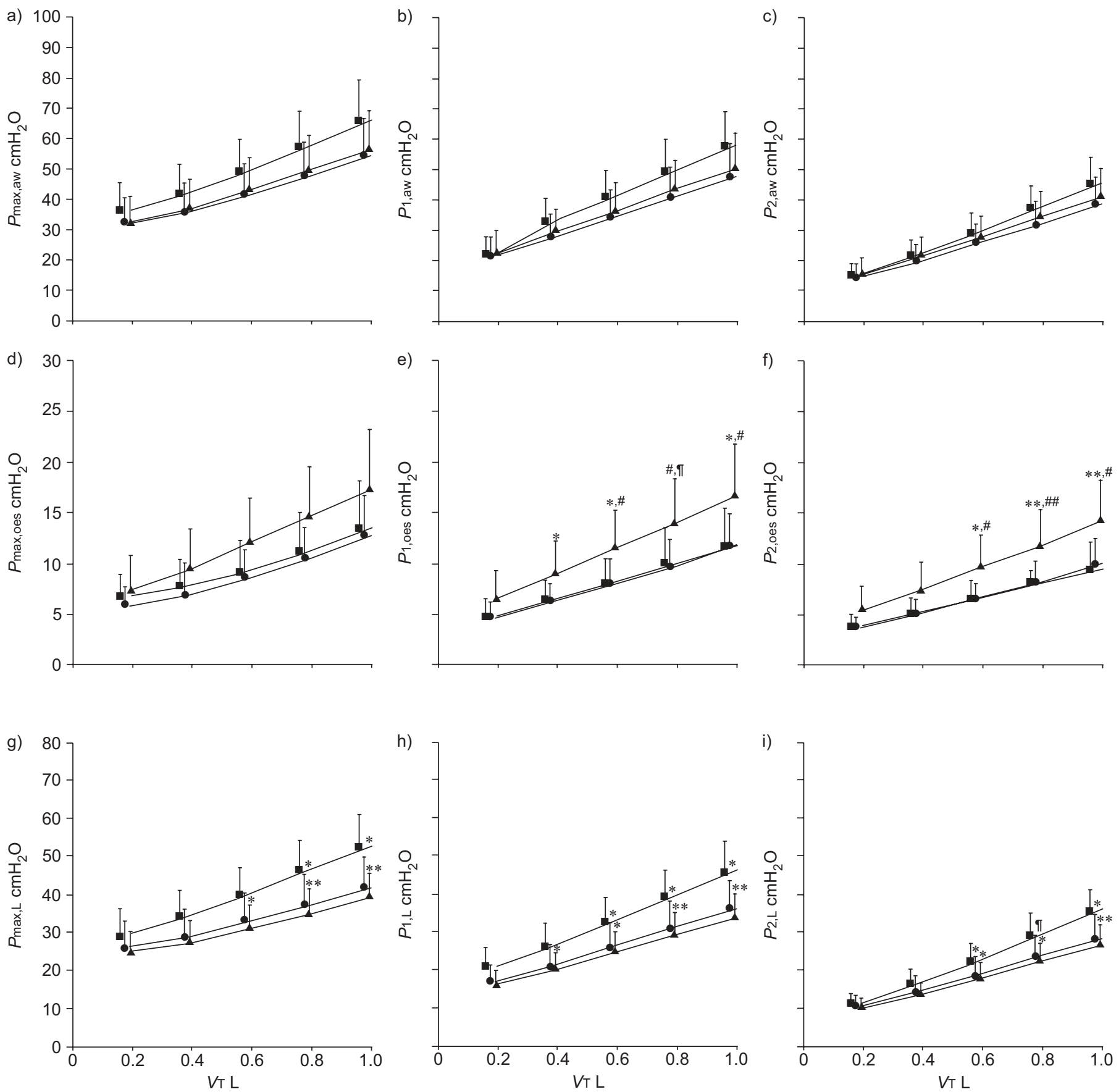

FIGURE 2. Results on tracheal (Paw), oesophageal (Poes) and transpulmonary $(P L)$ pressures from the iso-flow experiments. a-c) Average relationships of peak $P$ aw ( $\left(P_{\text {max }}\right.$ aw), Paw immediately after end-inspiratory airway occlusion $\left(P_{1}\right.$,aw), and plateau $P_{a w}\left(P_{2}\right.$,aw) with increasing inflation volume. $\left.d-f\right)$ Average relationships of peak $P_{\text {oes }}$

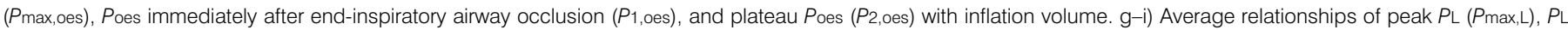
immediately after end-inspiratory airway occlusion $\left(P_{1}, \mathrm{~L}\right)$, and plateau $P \mathrm{~L}\left(P_{2, \mathrm{~L}}\right)$ with inflation volume $(\mathrm{VT})$. Symbols represent mean values and bars represent SD. $\mathbf{a}$ : pre-prone semirecumbent; $\bullet$ : post-prone semirecumbent; $\boldsymbol{\Lambda}$ : prone. *: $p<0.05$ versus pre-prone semirecumbent (SRBAS); ${ }^{*}$ : $p<0.01$ versus SRBAS; $\#$ : $p<0.05$ versus post-prone semirecumbent (SRPP); \#\#: $p<0.01$ versus SRPP; ${ }^{\circ}$ : trend towards significance versus SRBAS.

The $\mathrm{Pa}_{\mathrm{a}} \mathrm{CO}_{2}$ and physiological dead space reductions suggest an increase in effective alveolar ventilation [23]. The additional lung resistance decrease suggests a reduced time constant inequality range, more homogenous lung inflation, and reduced numbers of atelectatic and hyperinflated/overdistended alveoli $[14,23,30]$. The reduction in regional atelectasis attenuates the stress in neighbouring lung regions [46]. The reduction in regional hyperinflation or overdistension attenuates regional strain and reduces the regional probability of traumatic alveolar rupture [23]. Thus, although the current authors could not directly determine regional stress/strain, the combined results in the present study 

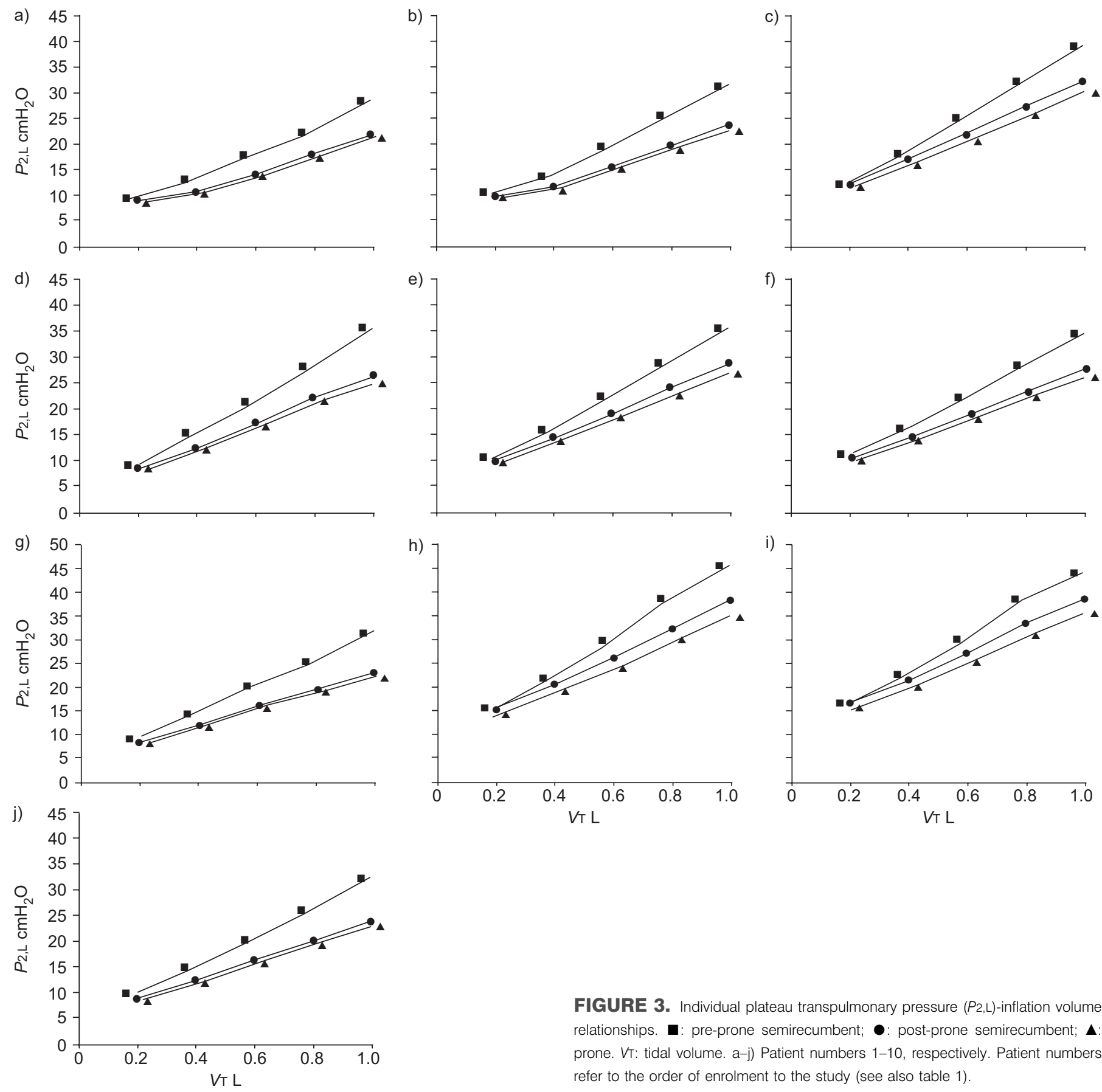

FIGURE 3. Individual plateau transpulmonary pressure $\left(P_{2, L}\right)$-inflation volume relationships. $\mathbf{\square}$ : pre-prone semirecumbent; $\bullet$ : post-prone semirecumbent; prone. VT: tidal volume. a-j) Patient numbers 1-10, respectively. Patient numbers refer to the order of enrolment to the study (see also table 1).

strongly suggest reduced "regional probability" of VILI in the prone position.

The observed significant decreases in $\mathrm{O}_{2} \mathrm{ER}$ were due to the simultaneous decreases in oxygen consumption and/or increases in oxygen delivery. These changes could be attributable to the effects of the probably slowly increasing plasma propofol and fenanyl concentrations throughout the study period [50]. Propofol/fentanyl anaesthesia reduces oxygen consumption in hypoxaemic respiratory failure patients [24]. Mild and moderate maintenance infusioninduced increases in propofol and fentanyl plasma concentrations, respectively [50], should not directly affect myocardial performance [51, 52]. The observed arithmetical decreases in heart rate could be attributable to fentanyl [53]. The heart rate changes could have contributed to the observed arithmetical increases in SRPP cardiac index (table 4) by improving cardiac diastolic filling, cardiac muscle fibre length-tension relationship, and consequently, cardiac contractility [54]. The speculation for improved diastolic filling is supported by the observed 


\begin{tabular}{|c|c|c|c|}
\hline TABLE 3 & $\begin{array}{l}\text { End-expirat } \\
\text { ventilation }\end{array}$ & ry lung volu & $n$ L) during ba \\
\hline $\begin{array}{l}\text { Patient } \\
\text { No. }\end{array}$ & $\begin{array}{c}\text { Pre-prone } \\
\text { semirecumbent }\end{array}$ & Prone & $\begin{array}{l}\text { Post-prone } \\
\text { semirecumbent }\end{array}$ \\
\hline 1 & 1.17 & 1.64 & 1.60 \\
\hline 2 & 1.09 & 1.57 & 1.50 \\
\hline 3 & 0.96 & 1.35 & 1.31 \\
\hline 4 & 1.05 & 1.54 & 1.45 \\
\hline 5 & 0.99 & 1.39 & 1.34 \\
\hline 6 & 1.02 & 1.51 & 1.42 \\
\hline 7 & 1.11 & 1.59 & 1.53 \\
\hline 8 & 0.89 & 1.33 & 1.26 \\
\hline 9 & 0.92 & 1.30 & 1.28 \\
\hline 10 & 1.14 & 1.61 & 1.58 \\
\hline Mean \pm SD & $1.03 \pm 0.09$ & $1.48 \pm 0.13^{\star *}$ & $1.43 \pm 0.12^{\star \star}$ \\
\hline
\end{tabular}

Data are presented as individual patient values. ${ }^{\star *}: p<0.01$ versus pre-prone semirecumbent.

increase in left ventricular SWI [55]. In SRPP, the improved haemodynamic performance could have contributed to the maintenance of the pronation gas exchange benefits relative to SRBAS. However, as in the case of the prone position, the major portion of the SRPP gas exchange improvement could still be explained by the still improved shunt fraction and physiological dead space (table 4), and thus, ventilationperfusion matching.

The determinations of Poes in different body postures may be problematic, despite prior relevant methodological interpretations [30, 33, 35, 38], and confirmation of an unchanged pattern of transmission of intracardiac pressure changes to the oesophageal balloon [23]. Pronation causes redistribution of regional lung collapse [56]; if this occurs in lung areas adjacent to the lower oesophagus, the patterns of intrapleural pressure transmission to the oesophageal balloon may differ between prone and semirecumbent postures, thus resulting in possible posture-related bias in $P \mathrm{~L}$ calculations. However, regional lung collapse, although different in amount, should tend to exhibit similar distribution in SRBAS and SRPP. This should have minimised the impact of the aforementioned potential problem upon the $P_{\mathrm{L}}$ results in the current study, because similar improvement in gas exchange, indicating similar amount of alveolar recruitment, was accompanied by similar reductions in $P_{\mathrm{L}}$ determined in prone and SRPP relative to SRBAS. Consequently, $P \mathrm{~L}$ was probably calculated in prone as accurately as in semirecumbent posture.

Pronation benefits were maintained during SRPP measurements; major contributory factors may include: 1) optimised PEEP-induced maintenance of overall pronation-induced alveolar recruitment, despite its posture-associated redistribution [56]; and 2) partial maintenance of a possible pronationinduced lower lung lobe decompression in steep semirecumbent posture [14]. The maintenance of lower lobe decompression could have been facilitated by the absence of abnormally raised intra-abdominal pressure and decreased abdominal compliance (table 2) [27].

\section{Clinical implications}

According to the lung stress/strain results presented in the current study, ventilation with standard $V$ Ts $\quad(0.6 \mathrm{~L}=$ $\left.9.0 \pm 0.9 \mathrm{~mL} \cdot \mathrm{kg}^{-1} \mathrm{PBW}\right)[9,39-42]$ in prone/SRPP is equally protective as ventilation with low VTs $\left(0.4 \mathrm{~L}=6.0 \pm 0.6 \mathrm{~mL} \cdot \mathrm{kg}^{-1}\right.$ PBW) [25] in SRBAS. Indeed, in prone and SRPP, $P 2, \mathrm{~L}$ and $P$ max,L values at baseline $(0.6 \mathrm{~L}) V \mathrm{~T}$ were similar to SRBASP2,L and $P$ max, $\mathrm{L}$ values at $0.4 \mathrm{~L} V$ T (fig. 2c). $V$ T/EELV (strain) was also similar in prone and SRPP at $0.6 \mathrm{~L} V$ T and SRBAS at $0.4 \mathrm{~L} V \mathrm{~T}$ $(0.39 \pm 0.04)$. Consequently, if in severe ARDS, low VTs are accepted as the "gold standard" in SRBAS [12, 25, 57], pronation may provide considerable "VT-liberation capability" by allowing a $50 \%\left(3 \mathrm{~mL} \cdot \mathrm{kg}^{-1} \mathrm{PBW}\right) V \mathrm{~T}$ increase, without appreciable increase in the VILI risk. Under PEEP optimisation, such $V$ T liberation may be allowable in SRPP for at least $2 \mathrm{~h}$.
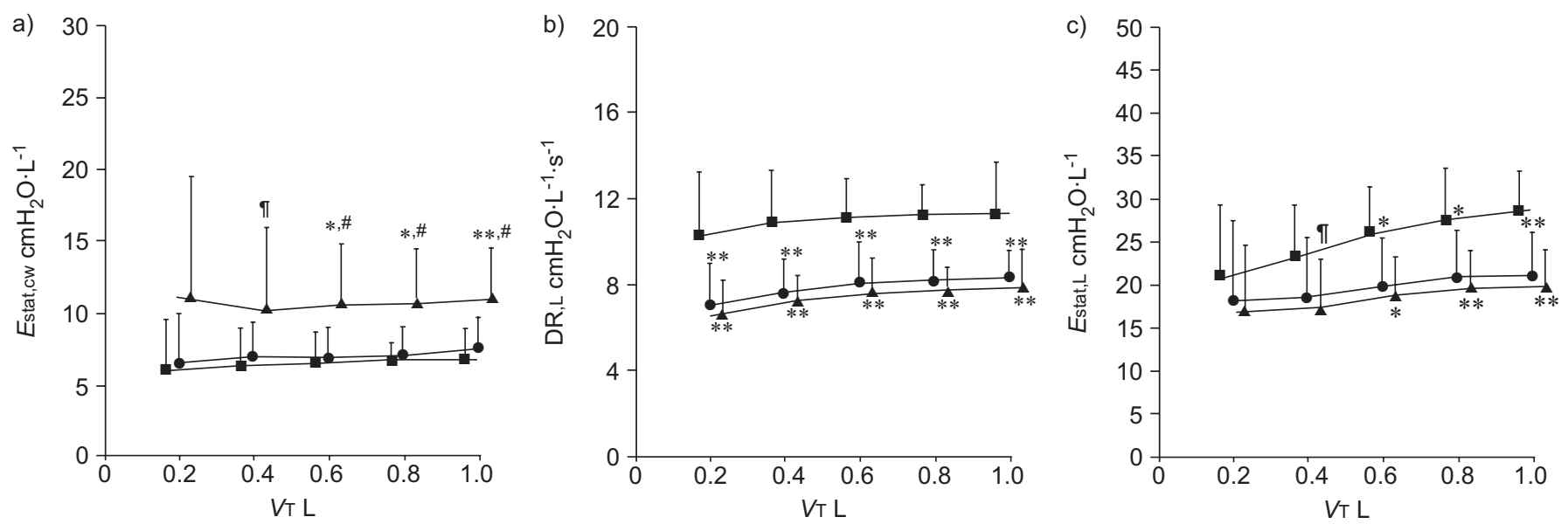

FIGURE 4. Partitioned respiratory mechanics. Data are presented as mean $\pm S D$.

pre-prone semirecumbent

post-prone semirecumbent; $\boldsymbol{\Delta}$ : prone. Symbols represent mean values and bars represent SD. Estat: static elastance; $\mathrm{cW}$ : chest wall; DR: additional resistance; L: lung. *: $p<0.05$ versus pre-prone semi-recumbent; **: $p<0.01$ versus pre-prone semirecumbent; $\#: p<0.05$ versus post-prone semirecumbent; ${ }^{\circ}$ : trend towards significance versus pre-prone semirecumbent. 


\begin{tabular}{|c|c|c|c|c|}
\hline \multirow[t]{3}{*}{ TABLE 4} & \multicolumn{4}{|c|}{$\begin{array}{l}\text { Haemodynamic and gas exchange variables. Gas } \\
\text { exchange results correspond to baseline } \\
\text { ventilation. }\end{array}$} \\
\hline & & \multicolumn{3}{|c|}{ Body posture } \\
\hline & & $\begin{array}{c}\text { BAS } \\
\text { semirecumben }\end{array}$ & Prone & $\begin{array}{l}\text { Post-prone } \\
\text { semirecumbent }\end{array}$ \\
\hline \multicolumn{5}{|c|}{ Haemodynamic variables } \\
\hline $\mathrm{HR}$ beats $\cdot \mathrm{m}$ & & $119 \pm 14$ & $113 \pm 13$ & $111 \pm 13$ \\
\hline MAP $\mathrm{mmHg}$ & & $71 \pm 7$ & $75 \pm 7$ & $76 \pm 7$ \\
\hline CVP $\mathrm{mmHg}$ & & $9 \pm 2$ & $10 \pm 2$ & $10 \pm 2$ \\
\hline MPAP $\mathrm{mmH}$ & & $27 \pm 4$ & $28 \pm 4$ & $28 \pm 4$ \\
\hline PAWP mmH & & $11 \pm 2$ & $11 \pm 2$ & $12 \pm 2$ \\
\hline $\mathrm{Cl} \mathrm{L} \cdot \mathrm{min}^{-1} \cdot \mathrm{m}$ & & $4.3 \pm 0.6$ & $4.4 \pm 0.7$ & $4.6 \pm 01.0$ \\
\hline SVRI dynes. & $\cdot \mathrm{cm}^{-5} \cdot \mathrm{m}^{-2}$ & $1181 \pm 242$ & $1218 \pm 278$ & $1215 \pm 312$ \\
\hline PVRI dynes. & $\cdot \mathrm{cm}^{-5} \cdot \mathrm{m}^{-2}$ & $293 \pm 50$ & $302 \pm 56$ & $300 \pm 68$ \\
\hline $\mathrm{V}^{\prime} \mathrm{O}_{2} \mathrm{~mL} \cdot \mathrm{min}$ & ${ }^{1} \cdot m^{-2}$ & $142 \pm 22$ & $148 \pm 25$ & $145 \pm 24$ \\
\hline $\mathrm{O}_{2} \mathrm{ER}$ & & $0.38 \pm 0.03$ & $0.35 \pm 0.02^{\#}$ & $0.32 \pm 0.02^{\# \cdot+}$ \\
\hline LVSWI $\mathrm{g} \cdot \mathrm{m}^{-}$ & & $29.4 \pm 3.3$ & $33.2 \pm 4.3$ & $35.7 \pm 6.6^{\bullet}$ \\
\hline \multicolumn{5}{|l|}{ Gas exchange } \\
\hline $\mathrm{Pa}, \mathrm{O}_{2} / \mathrm{Fi}_{\mathrm{i}, \mathrm{O}_{2} \mathrm{n}}$ & $\mathrm{mHg}$ & $86 \pm 7$ & $133 \pm 13^{\#}$ & $128 \pm 13^{\#}$ \\
\hline $\mathrm{Pa}, \mathrm{CO}_{2} \mathrm{mml}$ & & $49.4 \pm 1.6$ & $42.8 \pm 1.2^{\#}$ & $43.9 \pm 1.2^{\#}$ \\
\hline $\mathrm{pHa}$ & & $7.33 \pm 0.02$ & $7.40 \pm 0.01^{\#}$ & $7.39 \pm 0.01^{\#}$ \\
\hline $\mathrm{Pv}_{\mathrm{V}, \mathrm{O}_{2}} \mathrm{mmHg}$ & & $36.2 \pm 1.8$ & $41.5 \pm 1.7^{\#}$ & $43.2 \pm 2.1^{\#}$ \\
\hline $\mathrm{Sv}, \mathrm{O}_{2} \%$ & & $57 \pm 2$ & $66 \pm 2^{\#}$ & $69 \pm 2^{\#}$ \\
\hline $\mathrm{Pv}_{\mathrm{v}, \mathrm{CO}_{2} \mathrm{mmH}}$ & & $55.4 \pm 1.6$ & $48.1 \pm 1.3^{\#}$ & $49.4 \pm 1.3^{\#}$ \\
\hline $\mathrm{pHv}$ & & $7.28 \pm 0.02$ & $7.35 \pm 0.01^{\#}$ & $7.34 \pm 0.01^{\#}$ \\
\hline$Q S \cdot Q^{-1}$ & & $0.36 \pm 0.03$ & $0.24 \pm 0.03^{\#}$ & $0.26 \pm 0.03^{\#}$ \\
\hline$V_{d} \cdot V_{t}^{-1}$ & & $0.48 \pm 0.06$ & $0.33 \pm 0.08^{\#}$ & $0.35 \pm 0.07^{\#}$ \\
\hline
\end{tabular}

Data are presented as mean \pm SD. BAS: baseline; HR: heart rate; MAP: mean arterial pressure; CVP: central venous pressure; MPAP: mean pulmonary artery pressure; PAWP: pulmonary artery wedge pressure; $\mathrm{Cl}$ : cardiac index; SVRI: systemic vascular resistance index; PVRI: pulmonary vascular resistance index; $V^{\prime} \mathrm{O}_{2}$ : oxygen consumption; $\mathrm{O}_{2} E R$ : oxygen extraction ratio; LVSWI: left ventricular stroke work index; $\mathrm{Pa}, \mathrm{O}_{2}$ : arterial oxygen tension; $\mathrm{Fl}, \mathrm{O}_{2}$ : inspired oxygen fraction; $\mathrm{Pa}_{1} \mathrm{CO}_{2}$ : carbon dioxide arterial tension; $\mathrm{pHa}$ : arterial $\mathrm{pH} ; \mathrm{Pv}_{1} \mathrm{O}_{2}$ : mixed venous oxygen partial pressure; $\mathrm{Sv}, \mathrm{O}_{2}$ : mixed venous oxygen saturation; $\mathrm{Pv}_{1} \mathrm{CO}_{2}$ : mixed venous carbon dioxide partial pressure; $\mathrm{pHv}$ : mixed venous $\mathrm{pH}$; QS.QT ${ }^{-1}$ : shunt fraction; $V_{d} \cdot V_{t}^{-1}$ : physiological dead space. ${ }^{\#}: p<0.01$ versus SRBAS; ${ }^{\circ}: p<0.05$ versus pre-prone semirecumbent (SRBAS); ${ }^{+}: p<0.05$ versus prone. $1 \mathrm{mmHg}=0.133 \mathrm{kPa}$.

Sighs frequently improve oxygenation in ARDS [34, 48, 58]. The present authors administered 1.0-L sigh-test VTs (15.0 \pm $\left.1.5 \mathrm{~mL} \cdot \mathrm{kg}^{-1} \mathrm{PBW}\right)$, which resulted in significantly lower $\overline{P \mathrm{~L}}$ (fig. 3) and $V$ T/EELV in prone/SRPP. These results indicate a decreased probability of traumatic alveolar rupture, especially during frequent sigh administration $\left(1-3 \cdot \mathrm{min}^{-1}\right)[34,48]$.

\section{Conclusions}

Prone positioning of patients with early and severe acute respiratory distress syndrome reduces lung parenchyma stress and strain during mechanical ventilation. This suggests a reduced risk of ventilator-induced lung injury. Pronation also improves sigh safety and gas exchange efficiency. Under positive end-expiratory pressure optimisation, pronation benefits may be maintained in a post-prone semirecumbent position.

\section{ACKNOWLEDGMENTS}

The authors would like to thank M. Tzoufi for her valuable help in manuscript preparation.

\section{APPENDIX 1: INSPIRATORY MECHANICAL VARIABLES}

For the respiratory system, chest wall, and lung the following inspiratory mechanics-variables were determined: 1) maximal, interrupter, and additional resistances, computed respectively as $P \max -P_{2}, P \max -P_{1}$, and $P_{1}-P_{2}$ differences divided by the preceding inspiratory flow; and 2) dynamic, and static elastances, computed as respective $P_{1}-\mathrm{PEEP}$ tot and $P_{2}-$ PEEPtot differences divided by the administered $V \mathrm{~T}$. Lung interrupter resistance reflects "ohmic" airway resistance; lung additional resistance reflects lung tissue stress relaxation tension and time constant inequality.

\section{APPENDIX 2: FORMULAS USED TO DERIVE HAEMODYNAMIC AND GAS EXCHANGE VARIABLES}

Formulas used to derive haemodynamic and gas exchange variables $[59,60]$

1. Cardiac index $=\mathrm{CO} / \mathrm{BSA}$

2. Systemic vascular resistance index $=(\mathrm{MAP}-\mathrm{CVP}) \times$ $80 \times \mathrm{CI}^{-1}$

3. Pulmonary vascular resistance index $=($ MPAP-PAWP $) \times$ $80 \times \mathrm{CI}^{-1}$

4. Oxygen consumption per $\mathrm{m}^{2} \mathrm{BSA}=\mathrm{CI} \times 1.36 \times \mathrm{Hgb} \times\left(\mathrm{SaO}_{2}-\right.$ $\mathrm{SvO}_{2}$ )

5. Oxygen delivery per $\mathrm{m}^{2} \mathrm{BSA}=\mathrm{CI} \times 1.36 \times \mathrm{Hgb} \times \mathrm{Sa}_{1} \mathrm{O}_{2}$

6. Oxygen extraction ratio $=\left(\mathrm{Sa}_{1} \mathrm{O}_{2}-\mathrm{Sv}_{\mathrm{v}} \mathrm{O}_{2}\right) \times \mathrm{Sa}_{1} \mathrm{O}_{2}^{-1}$

7. $\mathrm{SVI}=\mathrm{CI} \times(\text { heart rate })^{-1}[61]$

8. Right ventricular stroke work index $=(\mathrm{MPAP}-\mathrm{CVP}) \times$ SVI $\times 0.0136$ [61]

9. Left ventricular stroke work index $=(\mathrm{MAP}-\mathrm{PAWP}) \times \mathrm{SVI} \times$ 0.0136 [61]

10. Respiratory Quotient $=($ FEY of carbohydrate intake $) \times 1.0+$ $(\mathrm{FEY}$ of protein intake $) \times 0.8+(\mathrm{FEY}$ of lipid intake $) \times 0.7$ [62]

11. Alveolar $\mathrm{PO}_{2}=P \mathrm{i}, \mathrm{O}_{2}-P A, \mathrm{CO}_{2} \times\left[\mathrm{FI}_{1} \mathrm{O}_{2}-\left(1-F \mathrm{I}, \mathrm{O}_{2}\right) \times \mathrm{R}^{-1}\right]$; $P \mathrm{i}, \mathrm{O}_{2}=F \mathrm{I}, \mathrm{O}_{2} \times(P \mathrm{~B}-47) ; P \mathrm{~A}, \mathrm{CO}_{2} \sim P \mathrm{a}, \mathrm{CO}_{2}$

12. $\mathrm{O}_{2}$ content of blood $=\mathrm{Hgb} \times 1.36 \times \mathrm{SO}_{2} \times 10-1+0.003 \times \mathrm{PO}_{2}$

13. Shunt fraction $=\left(\mathrm{C}_{\mathrm{c}, \mathrm{O}_{2}}-\mathrm{Ca}_{2} \mathrm{O}_{2}\right) \times\left(\mathrm{C}_{\mathrm{c}}, \mathrm{O}_{2}-\mathrm{Cv}_{\mathrm{v}} \mathrm{O}_{2}\right)-1$

CO: cardiac output $\left(\mathrm{L} \cdot \mathrm{min}^{-1}\right)$; BSA: body surface area $\left(\mathrm{m}^{2}\right)$; MAP: mean arterial pressure $(\mathrm{mmHg})$; CVP: central venous pressure $(\mathrm{mmHg}) ; 80$ : transformation factor of Wood units $\left(\mathrm{mmHg} \cdot \mathrm{L}^{-1} \cdot \mathrm{min}\right)$ to standard metric units $\left(\right.$ dynes $\left.\cdot \mathrm{s} \cdot \mathrm{cm}^{-5}\right) ; \mathrm{CI}$ : cardiac index $\left(\mathrm{L} \cdot \mathrm{min}^{-1} \cdot \mathrm{m}^{-2}\right)$; MPAP: mean pulmonary artery pressure (mmHg); PAWP: pulmonary artery wedge pressure $(\mathrm{mmHg}) ; 1.36: \mathrm{O}_{2}$ combining power of $1 \mathrm{~g}$ of haemoglobin $(\mathrm{mL})$; $\mathrm{Hgb}$ : haemoglobin concentration in $\mathrm{g} \cdot \mathrm{L}^{-1} ; \mathrm{Sa}_{1} \mathrm{O}_{2}$ : arterial $\mathrm{O}_{2}$ saturation; $\mathrm{Sv}_{\mathrm{v}} \mathrm{O}_{2}$ : mixed venous $\mathrm{O}_{2}$ saturation; $\mathrm{SVI}$ : stroke volume index (mL per heart beat); 0.0136: conversion factor pressure and volume units to work units $(\mathrm{g} \cdot \mathrm{m})$; FEY: fractional energy yield relative to total of prescribed nutritional support; $\mathrm{Pi}_{\mathrm{i}} \mathrm{O}_{2}$ : inspired $\mathrm{O}_{2}$ partial pressure $(\mathrm{mmHg}) ; \mathrm{PA}_{1} \mathrm{CO}_{2}$ : alveolar $\mathrm{CO}_{2}$ partial pressure $(\mathrm{mmHg})$; $\mathrm{R}$ : respiratory quotient; $P \mathrm{~B}$ : barometric pressure $(\mathrm{mmHg}) ; 47$ : water saturated vapour pressure at $37^{\circ} \mathrm{C}(\mathrm{mmHg}) ; 0.003: \mathrm{O}_{2}$ solubility coefficient at $37^{\circ} \mathrm{C}$ $\left(\mathrm{mL} \cdot \mathrm{dL}^{-1} \cdot \mathrm{mmHg}\right) ; \mathrm{PO}_{2}: \mathrm{O}_{2}$ partial pressure $(\mathrm{mmHg}) ; \mathrm{SO}_{2}$ : oxygen 
saturation; $\mathrm{C}_{\mathrm{c}, \mathrm{O}_{2}} / \mathrm{Ca}_{2} \mathrm{O}_{2} / \mathrm{CV}_{\mathrm{V}} \mathrm{O}_{2}: \mathrm{O}_{2}$ content in end-capillary/ arterial/mixed-venous blood, respectively.

$1 \mathrm{mmHg}=0.133 \mathrm{kPa}$.

\section{REFERENCES}

1 Slutsky AS, Tremblay LN. Multiple organ system failure. Is mechanical ventilation a contributing factor? Am J Respir Crit Care Med 1998; 157: 1721-1725.

2 Slutsky AS. Lung injury caused by mechanical ventilation. Chest 1999; 116: Suppl. 1, S9-S15.

3 Gattinoni L, Carlesso E, Cadringher P, Valenza $\mathrm{F}$, Vaginelli F, Chiumello D. Physical and biological triggers of ventilator-induced lung injury and its prevention. Eur Respir J 2003; 22: Suppl. 47, S15-S25.

4 Vlahakis NE, Schroeder MA, Limper AH, Hubmayr RD. Stretch induces cytokine release by alveolar epithelial cells in vitro. Am J Physiol 1999; 277: Suppl. 1, L167-L173.

5 Nahum A, Hoyt J, Schmitz L, Moody J, Shapiro R, Marini JJ. Effect of mechanical ventilation strategy on dissemination of intratracheally distilled Escherichia coli in dogs. Crit Care Med 1997; 25: 1733-1743.

6 Slutsky AS. The acute respiratory distress syndrome, mechanical ventilation, and the prone position. $N$ Engl J Med 2003; 345: 610-611.

7 Pelosi P, Crotti S, Brazzi L, Gattinoni L. Computed tomography in adult respiratory distress syndrome: what has it taught us? Eur Respir J 1996; 9: 1055-1062.

8 Puybasset L, Cluzel P, Gusman P, et al. Regional distribution of gas and tissue in acute respiratory distress syndrome I. Consequences for lung morphology. Intensive Care Med 2000; 26: 857-869.

9 Eichacker PQ, Gerstenberger ER, Banks SM, Cui X, Natanson C. Meta-analysis of acute lung injury and acute respirtory distress syndrome trials testing low tidal volumes. Am J Respir Crit Care Med 2002; 166: 1510-1514.

10 Pinsky MR. The haemodynamic consequences of mechanical ventilation: an evolving story. Intensive Care Med 1997; 23: 493-503.

11 Albert RK, Kirk W, Pitts C, Butler J. Extra-alveolar vessel fluid filtration coefficients in excised and in situ canine lobes. J Appl Physiol 1985; 59: 1555-1559.

12 The National Heart, Lung, and Blood Institute ARDS Clinical Trials Network. Higher versus lower positive endexpiratory pressures in patients with the acute respiratory distress syndrome. $N$ Engl J Med 2004; 351: 327-336.

13 Puybasset L, Gusman P, Muller JC, et al. Regional distribution of gas and tissue in acute respiratory distress syndrome III. Consequences for the effects of positive endexpiratory pressure. Intensive Care Med 2000; 26: 1215-1227.

14 Rouby JJ, Puybasset L, Nieszkowska A, Lu Q. Acute respiratory distress syndrome: lessons from computed tomography of the whole lung. Crit Care Med 2003; 31: Suppl. 4, S285-S295.

15 Vieira SR, Puybasset L, Lu Q, et al. A scanographic assessment of pulmonary morphology in acute lung injury: significance of the lower inflection point detected on the lung pressure-volume curve. Am J Respir Crit Care Med 1999; 159: 1612-1623.
16 Broccard AF, Shapiro RS, Schmitz LL, Adams AB, Nahum A, Marini JJ. Prone positioning attenuates and redistributes ventilator-induced lung injury in dogs. Crit Care Med 2000; 28: 295-303.

17 Nishimura M, Honda O, Tomiyama N, Johkoh $\mathrm{T}$, Kagawa K, Nishida T. Body position does not influence the location of ventilator-induced lung injury. Intensive Care Med 2000; 26: 1664-1669.

18 Albert RK, Hubmayr RD. The prone position eliminates compression of the lungs by the heart. Am J Respir Crit Care Med 2000; 161: 1660-1665.

19 Gattinoni L, Pelosi P, Vitale G, Pesenti A, D' Andrea L, Mascheroni D. Body position changes redistribute lung computed-tomographic density in patients with acute respiratory failure. Anesthesiology 1991; 74: 15-23.

20 Rouby JJ, Puybasset L, Cluzel P, et al. Regional distribution of gas and tissue in acute respiratory distress syndrome II. Physiological correlations and definition of an ARDS Severity Score. Intensive Care Med 2000; 26: 1046-1056.

21 Bernard GR, Artigas A, Brigham KL, et al. The AmericanEuropean consensus conference on ARDS. Definition, mechanisms, relevant outcomes, and clinical trial coordination. Am J Respir Crit Care Med 1994; 149: 818-824.

22 Pugh RN, Murray-Lyon IM, Dawson JL, Pietroni MC, Williams R. Transection of the esophagus for bleeding oesophageal varices. Br J Surg 1973; 60: 646-649.

23 Mentzelopoulos SD, Zakynthinos SG, Roussos C, Tzoufi MJ, Michalopoulos AS. Prone position improves lung mechanical behavior and enhances gas exchange efficiency in mechanically ventilated chronic obstructive pulmonary disease patients. Anesth Analg 2003; 96: 1756-1767.

24 Elsasser S, Schachinger H, Strobel W. Adjunctive drug treatment in severe hypoxic respiratory failure. Drugs 1999; 58: $429-446$.

25 The Acute Respiratory Distress Syndrome Network. Ventilation with lower tidal volumes as compared with traditional tidal volumes for acute lung injury and the acute respiratory distress syndrome. N Engl J Med 2000; 342: 1301-1308.

26 Baydur A, Behrakis PK, Zin WA, Jaeger M, Milic-Emili J. A simple method for assessing the validity of the esophageal balloon technique. Am Rev Respir Dis 1982; 126: 788-791.

27 Ranieri VM, Brienza N, Santostasi S, et al. Impairment of lung and chest wall mechanics in patients with acute respiratory distress syndrome. Role of abdominal distention. Am J Respir Crit Care Med 1997; 156: 1082-1091.

28 Diehl JL, Lofaso F, Deleuze P, Similowski T, Lemaire F, Brochard L. Clinically relevant diaphragmatic dysfunction after cardiac operations. Ann Thorac Surg 1994; 107: 487-498.

29 Johnson B, Richard JC, Straus C, Mancebo J, Lemaire F, Brochard L. Presssure-volume curves and compliance in acute lung injury. Evidence of recruitment above the lower inflection point. Am J Respir Crit Care Med 1999; 159: 1172-1178.

30 Pelosi P, Tubiolo D, Mascheroni D, et al. Effects of the prone position on respiratory mechanics and gas exchange during acute lung injury. Am J Respir Crit Care Med 1998; 157: 387-393.

31 Tantucci C, Corbeil C, Chasse M, Braidy J, Matar N, MilicEmili J. Flow resistance in patients with chronic obstructive 
pulmonary disease in acute respiratory failure. Am Rev Respir Dis 1991; 144: 384-389.

32 Guérin C, Coussa ML, Eissa NT, et al. Lung and chest wall mechanics in mechanically ventilated COPD patients. J Appl Physiol 1993; 74: 1570-1580.

33 Pelosi P, Croci M, Callapi E, et al. Prone positioning improves pulmonary function in obese patients during general anesthesia. Anesth Analg 1996; 83: 578-583.

34 Patroniti N, Foti G, Cortinovis B, et al. Sigh improves gas exchange and lung volume in patients with acute respiratory distress syndrome undergoing pressure support ventilation. Anesthesiology 2002; 96: 788-794.

35 Pelosi P, Croci M, Calappi E, et al. The prone positioning during general anesthesia minimally affects respiratory mechanics while improving functional residual capacity and increasing oxygen tension. Anesth Analg 1995; 80: 955-960.

36 Pelosi P, Croci M, Ravagnan I, et al. Respiratory system mechanics in sedated, paralyzed, morbidly obese patients. J Appl Physiol 1997; 83: 811-818.

37 Gattinoni L, Tognoni G, Pesenti A, et al. Effect of prone positioning on the survival of patients with acute respiratory distress syndrome. N Engl J Med 2001; 345: 568-573.

38 Milic-Emili J, Mead J, Turner JM. Topography of esophageal presssure as a function of posture in man. J Appl Physiol 1964; 19: 212-216.

39 Thompson BT, Hayden D, Matthay MA, Brower R, Parsons PE. Clinicians' approaches to mechanical ventilation in acute lung injury and ARDS. Chest 2001; 120: 1622-1627.

40 Esteban A, Anzueto A, Alia I, et al. How is mechanical ventilation employed in the intensive care unit? An international utilization review. Am J Respir Crit Care Med 2000; 161: 1450-1458.

41 Carmichael LC, Dorinsky PM, Higgins SB, et al. Diagnosis and treatment of acute respiratory distress syndrome in adults: an international survey. J Crit Care 1996; 11: 9-18.

42 Esteban A, Anzueto A, Frutos F, et al. Characteristics and outcomes in adult patients receiving mechanical ventilation: a 28-day international study. JAMA 2002; 287: 345-355.

43 Friedrich P, Krafft P, Hochleuthner H, Mauritz W. The effects of long-term prone positioning in patients with trauma-induced adult respiratory distress syndrome. Anesth Analg 1996; 83: 1206-1211.

44 Pelosi P, Bottino N, Chiumello D, et al. Sigh in supine and prone position during acute respiratory distress syndrome. Am J Respir Crit Care Med 2003; 167: 521-527.

45 Gattinoni L, Vagginelli F, Carlesso E, et al. Decrease in $\mathrm{PaCO}_{2}$ with prone position is predictive of improved outcome in acute respiratory distress syndrome. Crit Care Med 2003; 31: 2727-2733.

46 Mead J, Takishima T, Leith D. Stress distribution in lungs: a model of pulmonary elasticity. J Appl Physiol 1970; 28: 596-608.
47 Gattinoni L, Pelosi P, Crotti S, Valenza F. Effects of positive end-expiratory pressure on regional distribution of tidal volume and recruitment in adult respiratory distress syndrome. Am J Respir Crit Care Med 1995; 151: 1807-1814.

48 Pelosi P, Bottino N, Chiumello D, et al. Sigh in supine and prone position during acute respiratory distress syndrome. Am J Respir Crit Care Med 2003; 167: 521-527.

49 Mure M, Domino KB, Lindahl SGE, Hlastala MP, Altemeier WA, Glenny RB. Regional ventilation-perfusion distribution is more uniform in the prone position. J Appl Physiol 2000; 88: 1076-1083.

50 Glass PSA, Shafer SL, Reves JG. Intravenous drug delivery systems. In: Miller RD, ed. Anesthesia. 5th Edn. New York, Churchill Livingstone, 2000; pp. 377-412.

51 Quattara A, Langeron O, Souktani R, Mouren S, Coriat P, Riou B. Myocardial and coronary effects of propofol in rabbits with compensated cardiac hypertrophy. Anesthesiology 2001; 95: 699-707.

52 Kohno K, Takaki M, Ishioka K, et al. Effects of intracoronary fentanyl on left ventricular mechanoenergetics in the excised cross-circulated canine heart (revised publication). Anesthesiology 1997; 87: 658-666.

53 Lokker GJ, Mader RM, Rizovski B, et al. Negative chronotropic effects of fentanyl attenuate beneficial effects of dobutamine on oxygen metabolism: hemodynamic and pharmacokinetic interactions. J Pharmacol Exp Ther 1999; 290: 43-50.

54 Blanck TJJ, Lee DL. Cardiac Physiology. In: Miller RD, ed. Anesthesia. 5th Edn. New York, Churchill Livingstone, 2000; pp. 619-646.

55 Glower DD, Spratt JA, Snow ND, et al. Linearity of the Frank-Starling relationship in the intact heart: the concept of preload recruitable stroke work. Circulation 1985; 71: 994-1009.

56 Gattinoni L, Pelosi P, Vitale G, Pesenti A, D' Andrea L, Mascheroni D. Body position changes redistribute lung computed-tomographic density in patients with acute respiratory failure. Anesthesiology 1991; 74: 15-23.

57 Levy MM. PEEP in ARDS-how much is enough? N Engl J Med 2004; 351: 389-391.

58 Grasso S, Mascia L, Del Turco M, et al. Effects of recruiting maneuvers in patients with acute respiratory distress syndrome ventilated with protective ventilatory strategy. Anesthesiology 2002; 96: 795-802.

59 Mark JB, Slaughter TF, Reves JG. Cardiovascular monitoring. In: Miller RD, ed. Anaesthesia. 5th Edn. New York, Churchill Livingstone, 2000; pp. 1117-1230.

60 Moon ME, Camporesi EM. Respiratory monitoring. In: Miller RD, ed. Anaesthesia. 5th Edn. New York, Churchill Livingstone, 2000; pp. 1255-1296.

61 Marino PL. The pulmonary artery catheter. In: Marino PL, ed. The ICU book. 2nd Edn. Baltimore, Williams \& Wilkins, 1997; pp. 154-165.

62 Marino PL. Nutrient and energy requirements. In: Marino PL, ed. The ICU book. 2nd Edn. Baltimore, Williams \& Wilkins, 1997; pp. 721-736. 